\title{
THAKUR RAM: BASE CAMPUS FOR PROPOSED BIRGUNJ UNIVERSITY
}

\author{
Editorial Board \\ Academic Voices, TRM Campus, Birgunj
}

\section{Historical background}

Established in 2009 B.S, Thakur Ram Multiple Campus Birgunj has been one of the pioneering academic institutions not only in the Central Terai but in the entire country. Immediately after the establishment of democracy(2007 B.S.), the campus came into existence with an aim of meeting the aspiration of imparting higher education to the people of this region. The role of Krishna Bahadur Manandhar, Tej Bahadur Amatya and Raghuveer Ram and Mahaveer Prasad (members of Donor family of the campus) in the establishment of the campus can hardly be exaggerated. However, it was Jibneshwor Mishra who worked as a source of inspiration for them. It is the first campus to have been founded outside the Kathmandu valley, and the third in the whole country. During its inception, it was run under the affiliation of Patna University (India) and therefore is older than TU which was established in 2016 B.S. It has been an 'A class' constituent campus of TU since 2030 B.S.

On the completion of its successful five decades, the campus celebrated its Golden Jubilee in 2059 B.S. It was a matter of pride and satisfaction for the campus that it has been able to contribute considerably in the production of statesmen, literary figures, scholars, artists, social workers, industrialists, doctors and technical manpower within the period. Golden Jubilee proved to be a stimulating factor for its growth. The campus has since then steadily leaped forward not only in quantity but also in quality.

\section{Present status}

Consisting of four streams viz. Education, Management, Humanities \& Social Sciences and Science \& Technology, the campus runs a large number of academic programs from Bachelor to Master's level (Proficiency Certificate level has recently been phased out from TU) to cater to the educational needs of this arena..

The campus runs Master's degrees in different steams and subjects such as English Education, Mathematics Education, Health Education and Educational Planning \& Management. Likewise, the campus also runs programs M.B.S., M.A. in Political Science, History, Sociology and Population Studies. Apart from this, the campus has also proposed to run M. Ed. in Nepali and Population Education.

In addition to its regular teaching and learning activities, the campus has concentrated on innovations and research activities recently and the publication of this multidisciplinary journal indicates a step towards its academic growth. It has highly innovative academicians and professionals working in different faculties and departments. There are 25 teachers already awarded with Ph. D. degrees from different universities. Apart from this, a substantial number of teachers from the campus are pursuing M. Phil. and Ph. D. in 
reputed universities. In addition, teachers of this campus belong to different professional associations such as Research Society of Integrated Sciences (RESIS), Nepal English Language Teachers Association (NELTA), International Association of Teachers of English, International Association for Teachers of English as a Foreign Langauge (IATEFL), and Council for Mathematics Education (CME). These professional organizations organize various activities such as conferences, workshops etc. including publication of journals .

At present, there are three Professors, forty eight Associate Professors, sixty two Lecturers and thirty eight Teaching Assistants in the campus. The total number of non-teaching staff in different sections viz. Administration, Account, Examination, Library, Laboratory, Student Welfare etc. is one hundred eight. Likewise, the total number of students pursuing their higher education in different streams and levels is seven thousands two hundred and sixty.

The campus owns a large piece of land (22 bighas or 286 ropanis). It has three premises having seven blocks- three for classroom and one for library purpose, still two for hostels (Boys' and Girls') and one for teacher accommodation. It also has five science labs and one computer lab. The campus has a separate Block for Regional Library having a distinct section for Master's degree and a Research Centre which owns a few computers, multimedia projectors and also access to internet.

\section{Proposed Birgunj university}

In 2066 B.S., a proposal for the establishment of a university in Birgunj was submitted to the Ministry of Education and University Grants Commission on behalf of Thakur Ram Multiple Campus. The proposal forwarded the following justifications (Source: A Proposal for the Establishment of Thakur Ram University, 2066):
1. It can be argued that a university has a geographical locus and focus in the sense that it is expected to serve mainly the area of its location with focus on the needs of local society. This infers that higher education should have regional orientation which can better be guaranteed through the establishment of universities on regional basis.

2. Institutional autonomy is considered one of the important elements for the promotion of an institution as a university. TRM Campus already has been a decentralized constituent campus for a decade with its Master's programs in more than a dozen of subjects and it is the demand of the day that it becomes a fully autonomous institution to shoulder its responsibility in more accountable manner and with need based perspectives.

3. The concepts of Multi-university and Deemed university that University Grants Commission(UGC) of Nepal has envisaged recently allows providing quality education through different universities in different developmental regions and promotion of TRM campus as a base campus of the university will serve the policy.

4. Federalism is another factor that paves the way for establishing universities in different states. Birgunj is a strong candidate for the Headquarter of one of the Federal states of Nepal. And therefore, it feels necessary that a federal capital owns and operates a university of its own to provide excellent but demand driven education to its people.

5. Globalization has been conceived as a challenge as well as an opportunity. On agrees or not-a sizeable number of students from this region go abroad to pursue qualitative education. It is a challenge before us that a university is competitive enough to check the students' migration and also to make our own higher education compatible with that of international institutions. This is possible if a university emerges with such visions and dynamic leadership. 
6. Modern higher education has changed considerably. It has moved towards independence, flexibility, need-oriented, creative, critical, cost effective but also competitive. The state or centre cannot hold, direct and control the way higher education has leaped forward. Today, the state has more a supervisory role than that of interventionist. The state is to provide policy framework to co-ordinate, regulate, accredit and provide guidance and incentives for educational enhancement and has to promote autonomy.

7. Diversification of higher education is the need of the day. A university has to diversify its programs and structures to respond to the aspirations of the society to which it is to serve. Since Nepal is immensely diverse linguistically, culturally, ethnically, religiously and also from the perspective of social structures, one system cannot fit all.
8. The current gigantic size of the students and prospective pupil's strength, involvement of academically and professionally sound faculty members, dedicated and devoted administrative staff in the campus also induces to promote Thakur Ram as a base campus of the proposed university.

9. TU has 6o constituent and about 500 affiliated colleges which are unmanageable from all perspectives. There is no doubt to the fact that this extravagant quantity increment has badly impeded the quality that TU had been providing and is supposed to provide. Bearing $92 \%$ of load of higher education of the country seems strange for one institution. The establishment of a university will lessen the weight and pressure on the one hand and will ensure quality education with sizeable number of students. 